\title{
The influence of economic growth on regional disparities: Empirical evidence from OECD countries $^{* 1}$
}

\author{
Saša Obradović ${ }^{2}$, Nemanja Lojanica ${ }^{3}$, Olivera Jankovic ${ }^{4}$
}

\begin{abstract}
In the context of growing regional disparities which exist both in developed and developing countries, the primary goal of this paper is to examine the influence of total economic activities on regional disparities. In the research panel sample of the selected OECD countries has been used with the data for the time period from 2000 to 2011. The empirical analysis reveals that there is a long-term relationship between the variables, that economic growth and regional disparities move in the same direction and that the impact of economic growth on regional disparities is statistically significant. Consequently, in order to reduce regional disparities, it is necessary to increase the share of less developed regions in the total output. In this matter, it should be helpful to adequately coordinate policies about regional development from all levels of governance.
\end{abstract}

Key words: regional disparities, economic growth, panel sample, OECD countries

JEL classification: $C 23, R 11,040$

\footnotetext{
Received: 16-03-2016; accepted: 17-06-2016

1 This paper is a part of research project No. 179015, financed by the Ministry of Science and Education of the Republic of Serbia.

2 Associate Professor, Faculty of Economics, University of Kragujevac, Djure Pucara 3, 34000 Kragujevac, Serbia. Scientific affiliation: macroeconomics, applied econometrics. Phone: +381 34303 550.E-mail: sobradovic@kg.ac.rs.

3 Teaching Assistant, Faculty of Economics, University of Kragujevac, Djure Pucara 3, 34000 Kragujevac, Serbia. Scientific affiliation: macroeconomics, applied econometrics. Phone: +381 303 508.E-mail: nlojanica@kg.ac.rs.

4 Teaching Assistant, Faculty of Economics, University of Kragujevac, Djure Pucara 3, 34000 Kragujevac, Serbia. Scientific affiliation: mathematical economics. Phone: +381 303552. E-mail:ojankovic@kg.ac.rs.
} 


\section{Introduction}

In comparison to other theoretical disciplines, the theory of regional development has emerged relatively late. This is a result of the ruling theories of the classical school, which were the foundation of the development of civil economic thought in the second half of the nineteenth century. The concepts of the civil doctrine, including perfect competition and stable balance, exclude the possibility that any major disturbances in the regional development can exist, that can't be corrected by free operations of the market. The Great recession, which has emphasized the regional differences and provoked the growing engagement of a state in social and economic processes, has an important role in the abandonment of the doctrine of the classical school of economics. The interest for studying regional development is primarily motivated by the need to ensure its efficiency and eliminate all the factors that impede it.

Economic, social and regional cohesion has been observed as an essential part of regional policy. Regional disparities include divergence or inequality of properties, which do not have spatial allocation and which happen in at least two entities of territorial structure. Differences between countries are not often as large as disparities within them. In the majority of OECD countries, there was an increase in the regional disparities. At the time of global crisis, there was a decline in regional GDP in OECD countries. This period was also characterized by faster deterioration of the poorer regions which deepened the gap between the regions. Within this group, $10 \%$ of the regions with the best economic performance were responsible for 38\% of total GDP in 2010 (OECD, 2013).

Regional differences can have serious implications for the successful operations of a national economy. This applies to both developed and developing countries. Regional disparities can lead to unwanted migration of labor and capital from depressed to prosperous regions, spreading inflation in the opposite direction from prosperous to depressed regions, which eventually results in deterioration of total trade-off between inflation and unemployment (Cherodian and Thirlwall, 2015). Regional disparities in income largely depend on the difference in the regional economic structure. Regional economic structure significantly affects the gross added value of an employee. A larger share of the primary sector in a regional structure of an economy means lower gross added value. In addition, high polarization in income is the main source of social tensions, which increase sociopolitical instability between rich and poor areas. This may have a negative impact on economic growth. Economic policy holders are thus facing a very important task concerning the establishment of an adequate connection between regional disparities and economic growth. Achievement of high growth rate is certainly one of the most important goals of any national economy, but we should not undermine the issue of balanced regional development. Based on these outstanding problems 
which many economies are currently facing, the main objective of this paper is to test the intensity of the impact of economic growth on regional disparities in the OECD countries. Bearing in mind the above mentioned facts concerning the contributions of individual regions to the overall growth of a national economy, the premise of the research is as follows: economic growth causes an increase in regional disparities. In other words, economic growth has positive statistically significant impact on regional disparities in the studied countries. In this analysis, panel econometrics was selected as an appropriate methodological framework to examine causality and co-integration.

The rest of the article is structured as follows: the next segment of the paper emphasizes the importance of the problem of regional disparities highlighting its key determinants which have been recognized in the previous research. This segment also explains the key methodological approaches used in the examination of the relation between regional disparities and economic growth. The third part describes implemented models and methodology, and shows the basic tests we used. The sections following this one contain documentation background. It is important to note that the countries and regions selected for this particular study are given in the Appendix (see Table A1) of the paper. The fifth segment of the paper reveals the results of this study. Finally, the last segment of the paper is dedicated to concluding remarks where we discuss the results and highlight their implications for policy makers.

\section{Literature review}

The examination of the key factors that contribute to regional inequalities has been a subject of numerous theoretical and empirical studies in the recent years. The growing interest in this issue is related to the importance of investigating the determinants of the growth of national economies and the necessity to study regional development since contemporary economies are facing deepened regional disparities which create broad territorial deformations in form of depressed areas, super-concentrations, dominations and center-periphery conflict. From the standpoint of economic theory, there are many ambiguities and controversies regarding the factors that contribute to regional disturbances. On the basis of the importance of this problem, as well as the regional development itself, a lot of different options have been differentiated and formulated as theories including: location theory, growth pole theory, the theory of specialization and manufacturing complex, the neoclassical theory, the theory of circular cumulative causation, the doctrine of export orientation of the region and the contemporary concepts of the theory of regional development.

In this study of territorial disparities we have decided to use Williamson hypothesis as a starting point. According to this hypothesis, as national economy develops 
from early state, income inequalities between regions intensify to a certain level, after which inequality starts to converge (mature state). The factors affecting the level of regional inequality include labor migration, migration of capital, interconnectedness and government policy (Fisch, 1984). If we now turn on government policy and political decentralization, the results are inconclusive. Namely, according to Ezcurra and Rodrigues-Pose (2013) and Torrisi et al. (2015), the connection of political decentralization and regional inequalities are temporary and geographically uneven (Sorens, 2014). On the other hand, Kyriacou et al. (2015), point out that political decentralization enables the convergence in countries with good governance. Analyzing the evolution of long-term regional inequalities in Spain in the period from 1860-2000, Tapia and Martinez-Galarraga (2015) have found that economic growth and progressive integration of national markets follow an inverted shape " $U$ " in the context of regional income inequalities.

Regional disparities are present in many countries, despite the openness of national economies. Magrini (1999) emphasizes two important issues: the problem of defining the region and the nature of growth process which casts certain doubts about the validity of empirical results. According to Cuaresma et al. (2014) the key factors of regional disparities are differences in human capital between the regions which contribute to higher growth rates in the major cities. Also, regions which have rich natural resources and energy make regional disparities larger (Benin and Czyzewski, 2007).

Since the basic characteristics of modern economies are the openness of national borders and the rapid development of science and technology, there is a need to examine the factors of regional growth, due to growing competition regional economies are exposed to (Petrakos et al., 2007). A very important issue is to examine the impact of trade liberalization on regional disparities, because, according to Bachtler et al. (2000), foreign investors turn towards border areas or centers when they choose a place where to invest due to larger markets available there. Basic theoretical postulate of neoclassical theory is contained in the fact that the movement of capital from developed to undeveloped regions leads to regional differences in profit rates. The differences in the amount of profit determine the rate of movement of capital from developed to undeveloped regions. In contrast to the movement capital, labor moves from undeveloped towards developed regions. The speed of movement of labor force is determined by the amount of earnings in certain regions. According to the paradigm of the most famous advocate of this theory, Solow (1956), regional disparities are reduced under the influence of economic growth. Fingleton (2003) shares this opinion. Both authors highlight that it does not necessarily have to be so because of the decreases in return on capital. In a competitive environment, regional labor and capital mobility, as well as regional trade, will "work" for the benefit of price convergence and the strengthening of the negative ratio of growth and regional disparities (Petrakos et al., 2005). 
Other authors like Krugman (1991) and Romer (1986) claim that growth as spatially cumulative process increases regional differences to a great extent. Economic growth tends to be associated with some kind of agglomeration and it requires a minimum threshold of resources in order to take positions. Once that happens, it becomes self-sustaining, spatially selective and cumulative in its basis. Gurgul and Lach (2011) predict an uneven distribution of resources among the provinces in the region in transition countries. It is expected that more developed provinces, with more developed infrastructure and highly qualified workforce, will take victory in this competition, which will deepen the gap between the most developed (urban) and less developed (rural) areas.

Concerning the appropriate methodological framework, the previous studies have most commonly used the following two approaches: sigma and beta convergence and Granger causality. The first approach has been developed by Barro and Sala Martin (1991) who relate the problem of regional disparities with evaluated equation of convergence. A large number of authors (Quah 1997, Ezcurra et al., 2007) have pointed out numerous flaws in the implementation of this approach. In fact, this type of an analysis provides only a partial review of the observed distribution, ignores the possibility that regions cannot change their position during the study period and ignores the possibility of intra-distributional mobility. The results of the previous studies can be briefly summarized in the existence of moderate convergence or divergence. The recent development of spatial (spatial) econometric approach allows greater shading of regional disparities through empirical analysis, and thus highlights the important difference between the processes of convergence and divergence. Very interesting study regarding the influence of spatial correlation in income growth in the US states has been conducted by Garret et al. (2007). The authors emphasize the complex shape of spatial correlations since they have found a positive coefficient in the relation concerning the impact a growth in neighboring states has on the growth of each state.

In addition to the concept of beta and sigma convergence, empirical studies on regional disparities often use the idea of causality. Perez-Moreno (2009) has analyzed causality between economic growth and income inequality in Spanish regions for the period from 1970-2000. This relation has been examined using panel data analysis on the original data for each region with four time observations. Applying the Granger causality test, the study has shown that the gross domestic product per capita leads to lower income inequality. Ezcurra (2009) has also examined the causal link between the polarization of income and economic growth in the regions of the EU for the period from 1993 to 2003 and has found that the level of income polarization is negatively associated with the provincial growth. 


\section{Methodology}

Taking into consideration that the goal of this paper is to examine the impact of economic growth on regional disparities, the analysis begins with the following econometric model:

$$
R D_{i t}=\theta_{i}+\delta_{i} t+\beta \ln \left(G D P_{i t}\right)+\varepsilon_{i t} R D_{i t}=\theta_{i}+\delta_{i} t+\beta \ln \left(G D P_{i t}\right)+\varepsilon_{i t}
$$

where $i=1,2, \ldots, N$ is the country index, $t=1,2, \ldots, T$ is the time index, $R D_{i t}$ represents regional disparities and $\ln \left(G D P_{i t}\right)$ is gross domestic product per capita in form of logarithm. $\beta$ stands for long-term effects of gross domestic product per capita on regional disparities, while $\delta_{i} t$ represents country-specific deterministic time trends, and $\varepsilon_{i t}$ is error term.

In order to investigate the order of integration of the variables, we use panel unit root test developed by Im et al. 2003 (IPS). The basic hypothesis of this test implies mutual independence of cross-section data. IPS test examines the validity of the null hypothesis that all components are non-stationary $\left(\mathrm{H}_{0}: \rho_{i}=0\right)$, against alternative hypothesis that at least one of them is stationary $\left(\mathrm{H}_{1}: \rho_{i}<0\right.$, for $\mathrm{i}=1,2 \ldots N_{1 ;} \rho_{i}=0$, for $\left.i=N_{1}+1, N_{1}+2, \ldots N\right)$. Before the values of IPS test statistics are determined, the value of ADF statistics for each individual unit must be calculated. IPS test statistics is obtained through the correction of average value, which is defined in such a way that test statistics has normal distribution with 0 and 1 as parameters. Corrective factors differ in respect to the nature of deterministic component. The IPS test is based on the following autoregressive model.

$$
\Delta y_{i t}=\rho y_{i t-1}+z_{i t}^{\prime} \gamma+\Sigma_{j}^{p i} \varphi_{i j} \Delta y_{i t-j}+\varepsilon v_{i t}
$$

where $\Delta$ is the operator of the first difference, $p_{i}$ lag order and $z_{i t}^{\prime}$ represents the deterministic terms, such as fixed effects, or fixed effects combined with the individual time trend.

Two tests based on residual of evaluated co-integration equation are used to determine long-term relation, i.e. co-integration, between $\ln \left(G D P_{i t}\right)$ and $R D_{i t}$. We used Pedroni (1999) and Kao (1999) test of co-integration in a panel to test null hypothesis that residuals of evaluated co-integration relation are non-stationary. These approaches are equivalent to Engle-Granger (1987) two-stage procedure. Null hypotheses that variables are not co-integrated, i.e. that the series of residuals have a unit root is tested against the alternative that the variables in the panel are co-integrated, i.e. that the series is stationary. The Pedroni panel co-integration test can be shown in the following form:

$$
y_{i t}=\alpha_{i}+\rho_{i t}+\beta_{1 i} x_{1 i t}+\ldots+\beta_{M i} x_{M i t}+\epsilon_{i t}
$$


where $m=1, \ldots, M$ is a number of regressors, $\beta_{m}$ is a coefficient, $\alpha$ and $\rho$ represent deterministic components. Pedroni has defined seven types of tests. The first four tests are based on separate evaluation of the model for each individual unit. The variable dimension which evaluates co-integration is formed by grouping obtained residuals. This approach is in accordance with Levin et al. (2002) panel test of unit root. The second group of tests is used to evaluate each individual unit, and after that the relevant value of test statistics is formed according to average value of Dickey Fuller statistics for all $i$ values. This variant of testing corresponds to IPS panel test of unit root. Standardized distribution for the panel and grouped statistics can be shown in the following form:

$$
k=\frac{\varphi-\mu \sqrt{N}}{\sqrt{v}} \Rightarrow N(0,1)
$$

where $\varphi$ is the corresponding panel or group statistics, and $\mu$ and $\nu$ represent the expected mean and the variance of the appropriate statistics, which are tabulated in Pedroni (1999). To check the robustness of Pedroni's co-integration results, we use another panel co-integration test developed by Kao (1999). Kao has recommended five different types of Dickey Fuller tests, one of which corresponds to classical $\mathrm{ADF}$ test. The remaining three are: $\mathrm{DF}_{\rho}, \mathrm{DF}_{\mathrm{t}}, \mathrm{DF}^{*}, \mathrm{DF}_{\mathrm{t}}{ }^{*}$. The first three are based on powerful exogeneity of regressors and errors while the remaining two are based on the endogenous relation between regressors and errors. In asymptomatic conditions all five test statistics possess normal distribution with 0 and 1 as parameters.

We use between-dimension group-mean panel DOLS estimator developed by Pedroni (2001). The DOLS is a parametric approach and it is characterized by higher flexibility in respect to within-dimension approach, when heterogeneous co-integration vectors are present, i.e. in case when the effects of the independent on dependent variable are not the same in all countries under investigation. Also, in order to confirm the results, we use group-means FMOLS as non-parametric approach. Kao and Chiang (2000) have emphasized that DOLS is less biased in respect to FMOLS while Pedroni (2000) has indicated that there is a lower degree of distortion in DOLS than in FMOLS. Dynamic OLS in the panel model can be shown in the following form:

$$
y_{i t}=\theta+\delta_{i} t+\beta x_{i t}+\sum_{j=-p i}^{p i} \phi_{i j} \Delta x_{i t-j}+\varepsilon_{i t}
$$

where $\phi_{i j}$ represents the coefficients of the lead and lag differences. In order to determine short-term causality and to confirm long-term causality between the variables, we have used panel VECM model, i.e. it will include residual from DOLS long-term correlation:

$$
e c_{i t}=y_{i t}-\left[\hat{\theta}+\hat{\delta}_{i t}+\hat{\beta}_{i} x_{i t}\right]
$$

and ECT in simple panel of VECM model can be presented in the matrix form: 


$$
\left[\begin{array}{l}
\Delta y_{i t} \\
\Delta x_{i t}
\end{array}\right]=\left[\begin{array}{l}
c_{1 i} \\
c_{2 i}
\end{array}\right]+\sum_{j=1}^{k} \Gamma_{j}\left[\begin{array}{l}
\Delta y_{i t-j} \\
\Delta x_{i t-j}
\end{array}\right]+\left[\begin{array}{l}
\theta_{1} \\
\theta_{2}
\end{array}\right] e c_{i t-1}+\left[\begin{array}{l}
\varepsilon_{1 i t} \\
\varepsilon_{2 i t}
\end{array}\right]
$$

where $c_{i}$ represents fixed effects, $e c_{i t-1}$ represents error or deviation from equilibrium, while $\theta_{1}$ and $\theta_{2}$ are coefficients of adjustment and they show how dependent and independent variables react to deviations from the equilibrium state. Statistically significant and negative result for $e c_{i t}$ indicates long-term causality in the sense of Granger, as well as long-term endogenous variables (Hall and Milne, 1994). In order to determine short-term causality, i.e. short-term elasticity, we will use coefficients which stand by independent variables, with the note that the independent variables are displayed with an appropriate length of the delay. Also, both of the variables will be converted to the first difference, because by doing so they become stationary. In order to determine causality we use Granger test of non-causality developed by Dumitrescu and Hurlin (2012). This statistical test is based on Wald statistics which is averaged between units of cross-section data. This test takes into consideration cross-sectional dependence. This model starts with following linear relations:

$$
y_{i t}=\alpha_{i}+\Sigma_{k=1}^{K} \gamma_{i}^{(k)} y_{i t-k}+\Sigma_{k=1}^{K} \beta_{i}^{(k)} x_{i t-k}+\varepsilon_{i t}
$$

where $K$ is lag length which is identical for all countries under investigation in a balanced model, while $\alpha, \beta$ i $\gamma$ are parameters for evaluation. The basic hypothesis of this model is that autoregressive coefficients $\gamma_{i}^{(k)}$ and slope of regression coefficients $\beta_{i}^{(k)}$ are different for cross-section data.

\section{Empirical data and analysis}

In order to determine potential causality between the variables, the study includes the data for the 22 OECD countries for the time period from 2000 - 2011. Table 1 presents a complete review and all the explanations of variables used in modeling. The Appendix gives a review of the countries and their regions selected for this analysis based on Territorial Level 2 (TL2) in the OECD classification (see Table A1). Namely, those are the regions with the highest and the lowest GDP per head within the selected countries. The measure of regional disparity is obtained by putting those two values into ratio. It is important to note that the regions did not change their position during the time period selected for this analysis. In case of regional disparities, we use original data, while in terms of gross domestic product per head the analysis uses logarithm values for merely statistical reasons. To determine and evaluate causality and co-integration between the variables, longer observation period is required. Panel model provides opportunity to conduct this kind of examination even with shorter series because they represent combination of cross-section and time series data. In this case, we have the period of 12 
observations and 22 countries and taking into consideration that this is a balanced panel, the total number of observations equals 264 .

Table 1: Variable definition

\begin{tabular}{|l|l|l|l|}
\hline \multicolumn{1}{|c|}{ Variable } & Name in model & \multicolumn{1}{c|}{ Unit } & \multicolumn{1}{c|}{ Definition } \\
\hline $\begin{array}{l}\text { Gross domestic } \\
\text { product per head }\end{array}$ & lnGDP & logarithm & $\begin{array}{l}\text { Per head, constant prices, constant } \\
\text { PPP, OECD base year }\end{array}$ \\
\hline Regional disparities & RD & relation & $\begin{array}{l}\text { The biggest regional GDP per head/ } \\
\text { The lowest regional GDP per head }\end{array}$ \\
\hline
\end{tabular}

Source: Own concept based on data from OECD Regional Demographic Statistics

The Table 2 summarizes the values of descriptive statistics for both variables. It is interesting to emphasize that in 2001, the regional disparities were both the highest and the lowest.

Table 2: Summary of descriptive statistics

\begin{tabular}{|l|c|c|c|c|}
\hline \multicolumn{1}{|c|}{ Variable } & Mean & SD & Min & Max \\
\hline $\ln \left(\mathrm{GDP}_{\mathrm{it}}\right)$ & 10.208 & 0.339 & 9.236 & 10.807 \\
\hline $\mathrm{RD}_{\mathrm{it}}$ & 2.435 & 1.751 & 1.17 & 10.88 \\
\hline
\end{tabular}

Source: Authors' calculation

Minimal regional disparities were detected in Korea, while maximum values were recorded in Chile. In addition to Chile, in the given time period, the extremely high regional disparities were recorded in the USA and Slovakia. Plots of the data, for each country, are also provided in Appendix (see Figure A1).

\section{Results and discussion}

Table 3 shows the results of the tests of stationarity for $\ln \left(G D P_{i t}\right)$ and $R D_{i t}$. The null hypothesis $\left(\mathrm{H}_{0}\right.$ : Unit root) about the existence of unit root in both variables on level data is accepted. On the other hand, after the conversion of the variables into the first difference, they became stationary (the null hypothesis about the unit root is rejected), and the result obtained is statistically significant. Thus, based on the result of panel test of unit root, both variables are of order of integration I (1). Such result simultaneously represents a necessary precondition for the examination of co-integration of the variables. 
Table 3: Results of panel unit root test

\begin{tabular}{|l|c|c|}
\hline \multirow{2}{*}{ Series } & \multicolumn{2}{|c|}{ Constant } \\
\cline { 2 - 3 } & 0.1471 & Constant and trend \\
\hline $\ln \left(\mathrm{GDP}_{\mathrm{it}}\right)$ & 2.0021 & 2.7986 \\
\hline $\mathrm{RD}_{\mathrm{it}}$ & $-3.9079^{*}$ & -0.2511 \\
\hline$\Delta \ln \left(\mathrm{GDP}_{\mathrm{it}}\right)$ & $-8.1723^{*}$ & $-1.8654^{* *}$ \\
\hline$\Delta \mathrm{RD}_{\mathrm{it}}$ & $-5.8342^{*}$ \\
\hline
\end{tabular}

Notes: Lag length is in all cases 1 , according to Schwarz criterion, ${ }^{*}$ and ${ }^{* *}$ represent $1 \%$ and $5 \%$ of the test significance.

Source: Authors' calculation

Table 4 shows the results of Pedroni (1999) test. The majority of tests confirm a long-term association of variables.

Table 4: Pedroni co-integration test results

\begin{tabular}{|l|l|c|c|}
\hline \multicolumn{4}{|c|}{ Series: $\mathrm{RD}_{\mathrm{it}} \ln \left(\mathrm{GDP}_{\mathrm{it}}\right)$} \\
\hline \multirow{4}{*}{ Within dimension } & \multicolumn{1}{|c|}{ Test-Statistics } & Statistics & Weighted Statistics \\
\cline { 2 - 4 } & Panel v-Statistics & $2.4972^{*}$ & -0.7581 \\
\cline { 2 - 4 } & Panel rho-Statistics & $-1.9977^{* *}$ & 1.8991 \\
\cline { 2 - 4 } & Panel PP-Statistics & $-10.9759^{*}$ & $-2.6496^{*}$ \\
\cline { 2 - 4 } & Panel ADF-Statistics & $-12.0347^{*}$ & $-6.1068^{*}$ \\
\hline \multirow{3}{*}{ Between dimension } & Group rho-Statistics & 2.9933 & - \\
\cline { 2 - 4 } & Group PP-Statistics & $-3.9528^{*}$ & - \\
\cline { 2 - 4 } & Group ADF-Statistics & $-5.5410^{*}$ & - \\
\hline
\end{tabular}

Note: ${ }^{*}$ and ${ }^{* *}$ refer to $1 \%$ and $5 \%$ of the test significance.

Source: Authors' calculation

Table 5 shows the Kao (1999) results. The results are the same as in Pedroni, so we must conclude that there is co-integration between the variables.

Table 5: Kao's residual co-integration test results

\begin{tabular}{|c|l|c|c|}
\hline \multicolumn{4}{|c|}{ Series: $\mathrm{RD}_{\mathrm{it}} \ln \left(\mathrm{GDP}_{\mathrm{it}}\right)$} \\
\hline Dependent variable & \multicolumn{1}{|c|}{ Tests } & t-statistics & Probability \\
\hline \multirow{3}{*}{$\mathrm{RD}_{\mathrm{it}}$} & $\mathrm{ADF}$ & $6.0753^{*}$ & 0.0000 \\
\cline { 2 - 4 } & Residual variance & 0.0311 & - \\
\cline { 2 - 4 } & HAC variance & 0.0262 & - \\
\hline
\end{tabular}

Note: Asterisk ${ }^{*}$ refers to $1 \%$ of the test significance. HAC represents Autoregressive Heteroscedastic Consistent Standard Errors.

Source: Authors' calculation 
After we have determined the existence of co-integration between the variables in a panel, it is necessary to evaluate long-term parameters. Based on the analysis, it is evident that there is a positive and statistically significant relation between the variables, which is consistent with the assumptions that have been made in this paper. The coefficient of elasticity in respect to economic growth and regional disparity is 0.3555 . The interpretation of this result would be as follows: in the long run, an increase in economic growth rate for $1 \%$, increases the rate of regional disparities in observed countries for about $0.35 \%$. FMOLS confirms the significant positive relation between the variables, and the value of the coefficient is very close to DOLS, which gives more importance to the results. This result indicates that there is the strong impact of economic growth on the regional disparities. The reason for this lies in the fact that the main cities and Metropolitan areas are the key contributors to overall national performance.

Table 6: Results of panel estimates of the long-run relationship

\begin{tabular}{|l|c|c|c|c|}
\hline \multicolumn{5}{|c|}{ Dependent variable: $\mathrm{RD}_{\mathrm{it}}$, Panel DOLS } \\
\hline \multicolumn{1}{|c|}{ Variable } & Coefficient & Standard error & t-statistics & Probability \\
\hline $\ln \left(\mathrm{GDP}_{\mathrm{it}}\right)$ & 0.3555 & 0.1832 & $1.9409^{* *}$ & 0.0444 \\
\hline \multicolumn{5}{|c|}{ Dependent variable: $\mathrm{RD}_{\mathrm{it}}$, Panel FMOLS } \\
\hline Variable & Coefficient & Standard error & t-statistics & Probability \\
\hline $\ln \left(\mathrm{GDP}_{\mathrm{it}}\right)$ & 0.3195 & 0.0239 & $13.3606^{*}$ & 0.0000 \\
\hline
\end{tabular}

Notes: Leads and lags are determined by the Schwarz criterion, ${ }^{*},{ }^{* *}$ refer to $1 \%$ and $5 \%$ of the test significance respectively.

Source: Authors' calculation

The results, obtained by applying VECM model, for short-term (and long-term) causality between variables are presented in Table 7 .

Table 7: Panel Vector Error correction model: long-run and short-run causality

\begin{tabular}{|l|c|}
\hline \multicolumn{1}{|c|}{ Independent variables } & Dependent variable \\
\cline { 2 - 2 } & $\Delta \mathrm{RD}_{\mathrm{it}}$ \\
\hline $\mathrm{ec}_{\mathrm{it}-1}$ & $-0.5752(-3.7071)^{*}$ \\
\hline$\Delta \mathrm{RD}_{\mathrm{it}-1}$ & $0.413(0.2629)^{*}$ \\
\hline$\Delta \ln \left(\mathrm{GDP}_{\mathrm{it}-1}\right)$ & $-0.0906(-0.2572)$ \\
\hline
\end{tabular}

Notes: Asterisk ${ }^{*}$ refers to $1 \%$, of the test significance. Figures in brackets refer to the value of the t statistics.

Source: Authors' calculation 
Firstly, negative and statistically significant result for error correction term with one lag, confirms long-term relation between economic growth and regional disparities. On the other hand, in short run, the relation between variables is not confirmed, and the focus of attention will be on the analysis of long-term results.

The examination of panel causality through Dumitrescu Hurlin Panel Causality Test (2012) has revealed bidirectional causality between the variables, i.e. changes in economic growth lead to changes in regional disparities and vice versa.

Table 8: Pairwise Dumitrescu Hurlin panel causality test

\begin{tabular}{|l|c|c|c|}
\hline \multicolumn{5}{|c|}{ Pairwise Dumitrescu Hurlin Panel Causality Test } \\
\hline Lag 1 is determined by Akaike Information Criterion \\
\hline $\mathrm{H}_{0}$ & W-Statistics & Zbar-Statistics & Probability \\
\hline $\ln \left(\mathrm{GDP}_{\mathrm{it}}\right)$ does not homogenously cause $\mathrm{RD}_{\mathrm{it}}$ & 2.701 & 2.576 & $0.011^{* *}$ \\
\hline $\mathrm{RD}_{\mathrm{it}}$ does not homogenously cause $\ln \left(\mathrm{GDP}_{\mathrm{it}}\right)$ & 3.021 & 3.173 & $0.000^{*}$ \\
\hline
\end{tabular}

Notes: ${ }^{*}$ and ${ }^{* *}$ refers to $1 \%$ and $5 \%$ of the test significance.

Source: Authors' calculation

This test starts with null hypothesis that there is no homogenous causality from one towards the other variable. In this particular case, the null hypothesis has been rejected and bidirectional homogenous causality between economic growth and regional disparity in case of OECD countries for the time period from 2000 to 2011 is confirmed. This result shows that the height of regional disparities is changing simultaneously with changes in economic growth and vice versa.

\section{Conclusions}

The presented results of our analysis have proved our initial hypothesis that economic growth causes an increase in regional disparities. The empirical results are completely in accordance with a fact that the income in total gross domestic product of metropolis areas is above $50 \%$ in selected OECD countries. In addition, $50 \%$ of the population lives in metropolis areas, which comprises about $6 \%$ of total OECD area. Thus it is clear why the consequences of this include the devastation of rural areas and strong disparities. This research contributes to economic science by filling the gap in the existing empirical literature by focusing on the study of regional disparities-economic growth nexus, using specific data set for selected OECD countries. Also, this research contributes to the existing economic literature by applying methodology which is not often used in this specific area. Due to limited availability of data on regional GDP in longer temporal dimensions, the number of observations is not high which may be one of the limitations of this study. In terms of analysis and findings, this 
study is based on the bivariate model which can be subject to some omission. In the context of future research it would be important to include other indicators of regional disparities, in addition to regional gross domestic product per capita, such as regional (un)employment, business demography, and regional budget income, and to test their relation with economic growth. Finally, the recommendations to economic policy makers should be directed towards increasing the attention on regional disparities, i.e. towards increasing regional gross domestic product of less developed regions, in order to reduce regional disparities. Less developed regions can become competitive with corresponding combination of policies and at the first place by adequate coordination on all levels of governing, which implies appropriate institutional and organizational structure.

\section{References}

Bachtler, J., Downes, R., Gorzelak, G. (2000) Transition, Cohesion and Regional Policy in Central and Eastern Europe, Aldershot: Ashgate Publishers.

Barro, R., Sala-I-Martin, X. (1991) "Convergence across States and Regions", Brookings Papers on Economic Activity, Vol. 1991, No. 1, pp. 107-182, doi: 10.2307/2534639.

Benini, R., Czyzewski, A. (2007) "Regional disparities and economic growth in Russia: new growth patterns and catching up", Economic Change and Restructuring, Vol. 40, No. 1, pp. 91-135, doi: 10.1007/s10644-007-9026-0.

Cherodian, R., Thirlwall, A. P. (2015) "Regional disparities in per capita income in India: Convergence or Divergence?", Journal of Post Keynesian Economics, Vol. 37, No. 3, pp. 384-407, doi: 10.1080/01603477.2015.1000109.

Cuaresma, C. J., Doppelhofer, G., Feldkircher, M. (2014) "The Determinants of Economic Growth in European Regions", Regional Studies, Vol. 48, No. 1, pp. 44-67, doi: 10.1080/00343404.2012.678824.

Dumitrescu, E. I., Hurlin, C. (2012) "Testing for Granger non-causality in heterogeneous panels", Economic Modelling, Vol. 29, No. 4, pp. 1450-1460, doi: 10.1016/j. econmod.2012.02.014.

Engle, R., Granger, C. (1987) “Co-Integration and Error Correction: Representation, Estimation, and Testing", Econometrica, Vol. 55, No. 2, pp. 251-276, doi: $10.2307 / 1913236$.

Ezcurra, R., Rodrigues-Pose, A. (2013) "Political Decentralization, Economic Growth and Regional Disparities in the OECD", Regional Studies, Vol. 47, No. 3, pp. 388-401, doi:10.1080/00343404.2012.731046.

Ezcurra, R. (2009) "Does Income Polarization Affect Economic Growth? The Case of the European Provinces", Regional Studies, Vol. 43, No. 2, pp. 267-285, doi: 10.1080/00343400701808899. 
Ezcurra, R., Pascual, P., Rapun, M. (2007) "The dynamics of regional disparities in Central and Eastern Europe during Transition", European Planning Studies, Vol. 15, No. 10, pp. 1397-1421, doi: 10.1080/09654310701550850.

Fingleton, B. (2003) "Externalities, Economic Geography, And Spatial Econometrics: Conceptual and Modelling Developments", International Regional Science Review, Vol. 26, No. 2, pp. 197-207, doi: 10.1177/0160017602250976.

Fisch, O. (1984) "Regional Income Inequality and Economic Development", Regional Sciences and Urban Economics, Vol. 14, No. 1, pp. 89-111, doi: 10.1016/0166-0462(84)90045-0 .

Garrett, T., Wagner, G., Wheelock, D. (2007) "Regional disparities in the spatial correlation of state income growth, 1977-2002", The Annals of Regional Science, Vol. 41, No. 3, pp. 601-618, doi: 10.1007/s00168-007-0114-x.

Gurgul, H. Lach, L. (2011) "The impact of regional disparities on economic growth", MPRA Paper No. 52258.

Hall, S. Milne, A. (1994) “The relevance of P-star Analysis to UK Monetary Policy", Economic Journal, Vol. 104, No. 424, pp. 597-604, doi: 10.2307/2234634.

Im, K., Pesaran, H., Shin, Y. (2003) “Testing for unit roots in heterogeneous panels”, Journal of Econometrics, Vol. 115, No. 1, pp. 53-74, doi: 10.1016/s03044076(03)00092-7.

Kao, C., Chiang, M. H. (2000) "On the Estimation and Inference of a Co-integrated Regression in Panel Data", In Baltagi, B. H., Fomby, T., F. R., Hill, C. (eds.) Nonstationary Panels, Panel Co-integration, and Dynamic Panels (Advances in Econometrics, Volume 15), Emerald Group Publishing Limited, doi: 10.1016/ s0731-9053(00)15007-8.

Kao, C. (1999) "Spurious regression and residual-based tests for cointegration in panel data", Journal of Econometrics, Vol. 90, No. 1, pp. 1-44, doi: 10.1016/ s0304-4076(98)00023-2.

Krugman, P. (1991) "Increasing returns and economic geography", Journal of Political Economy, Vol. 99, No 3. pp. 483-499, doi: 10.1086/261763.

Kyriacou, A., Muinelo-Gallo, L., Roca-Sagales, O. (2015) "Fiscal decentralization and regional disparities: The importance of good governance", Papers in Regional Science, Vol. 94, No. 1, pp. 89-107, doi: 10.1111/pirs.12061.

Levin, A., Lin, C. F., Chu, J. (2002) "Unit root tests in panel data: Asymptotic and finite - sample properties", Journal of Econometrics, Vol. 108, No. 1, pp. 1-24, doi: 10.1016/s0304-4076(01)00098-7.

Magrini, S. (1999) "The evolution of income disparities among the regions of the European Union", Regional Science and Urban Economics, Vol. 29, No. 2, pp. 257-281, doi: 10.1016/s0166-0462(98)00039-8.

OECD (2015) Regional Demographic Statistics, [Internet]. Available at: < https://stats. oecd.org/Index.aspx?DataSetCode=REG_DEMO_TL2 $>$ [Accessed: December $15,2015]$. 
OECD (2013) OECD Regions at a glance ( $5^{\text {th }}$ Edition), December 5, 2013, doi: 10.1787/reg glance-2013-en.

Pedroni, P. (2001) "Purchasing Power Parity Tests in Co-integrated Panels", The Review of Economics and Statistics, Vol. 83, No. 4, pp. 727-731, doi: 10.1162/003465301753237803.

Pedroni, P. (2001) "Fully Modified OLS for Heterogeneous Cointegrated Panels", In Baltagi, B. H., Fomby, T., F. R., Hill, C. (eds.) Nonstationary Panels, Panel Cointegration, and Dynamic Panels (Advances in Econometrics, Volume 15), Emerald Group Publishing, doi: 10.1016/s0731-9053(00)15004-2.

Pedroni, P. (1999) "Critical values for co-integration tests in heterogeneous panels with multiple regressors", Oxford Bulletin of Economics and Statistics, Vol. 61, Special Issue, pp. 653-670, doi: 10.1111/1468-0084.61.s1.14.

Pérez-Moreno, S. (2009) "An Assessment of the Causal Relationship between Growth and Inequality in Spanish Provinces", European Planning Studies, Vol. 17, No. 3, pp. 389-400, doi: 10.1080/09654310802625296.

Petrakos, G., Kallioras, D., Anagnostou, A. (2007) "A Generalized Model of Regional Economic Growth in the European Union", Lessons and Policy Implications for the EU, Working Papers DYNREG Dynamic Regions in a Knowledge-Driven Global Economy.

Petrakos, G., Rodriguez-Pose, A., Rovolis, A. (2005) "Growth, integration, and regional disparities in the European Union", Environment and Planning, Vol. 37, No. 10, pp. 1837-1855, doi: 10.1068/a37348.

Quah, D. (1997) "Empirics for growth and distribution: Stratification, polarization and convergence clubs", Journal of Economic Growth, Vol. 2, No. 1, pp. 27-59, doi: 10.1023/a:1009781613339.

Romer, P. (1986) "Increasing returns and long-run growth", Journal of Political Economy, Vol. 94, No. 5, pp. 1002-1037, doi: 10.1086/261420.

Solow, R. (1956) "A contribution to the theory of economic growth", Quarterly Journal of Economics, Vol. 70, No. 1, pp. 65-94, doi: 10.2307/1884513.

Sorens, J. (2014) "Does Fiscal Federalism Promote Regional Inequality? An Empirical Analysis of the OECD, 1980-2005”, Regional Studies, Vol. 48, No. 2, pp. 239-253, doi: 10.1080/00343404.2012.661851.

Tapia, F., Martinez-Galarraga, J. (2015) "Inequality and poverty in a developing economy: Evidence from regional data (Spain, 1860-1930)", Working Papers 0078, European Historical Economics Society (EHES).

Torrisi, G. et al. (2015) "(Re-)exploring the link between decentralization and regional disparities in Italy”, Regional Studies, Regional Science, Vol. 2, No. 1, pp. 123-140, doi: 10.1080/21681376.2015.1007159. 
Utjecaj ekonomskog rasta na regionalne disparitete: empirijska evidencija iz OECD zemalja ${ }^{1}$

\author{
Saša Obradović ${ }^{2}$, Nemanja Lojanica ${ }^{3}$, Olivera Janković ${ }^{4}$
}

\begin{abstract}
Sažetak
U kontekstu sve većih regionalnih razlika koje su prisutne, kako u razvijenim, tako $i$ u zemljama u razvoju, osnovni cilj ovoga rada je ispitati utjecaj ukupne gospodarske aktivnosti na regionalne disparitete. U radu je korišten panel uzorak odabranih OECD zemalja, a vremensko određenje je 2000. - 2011. U okviru empirijske analize utvrđeno je da postoji dugoročna povezanost varijabli, kao i da se gospodarski rast i regionalne razlike kreću u istom smjeru, i da je taj utjecaj snažan $i$ statistički značajan. Shodno tome, u cilju smanjenja regionalnih dispariteta neophodno je da slabije razvijene regije sudjeluju s većim postotkom $u$ ukupnom ostvarenom društvenom proizvodu, u čemu će pomoći adekvatna koordinacija politika usmjerena prema regionalnom razvoju na svim razinama vlasti.
\end{abstract}

Ključne riječi: regionalni dispariteti, ekonomski rast, panel uzorak, OECD zemlje

JEL klasifikacija: C23, R11, O40

${ }_{1}$ Ovaj rad je dio istraživačkog projekta pod šifrom 179015, financiran od Ministarstva znanosti i obrazovanja Republike Srbije.

${ }^{2}$ Izvanredni profesor, Ekonomski fakultet, Sveučilište u Kragujevcu, Djure Pucara 3, 34000 Kragujevac, Srbija. Znanstveni interes: makroekonomija, primijenjena ekonometrija. Tel.: +38134303 550.E-mail: sobradovic@kg.ac.rs.

3 Asistent, Ekonomski fakultet, Sveučilište u Kragujevcu, Djure Pucara 3, 34000 Kragujevac, Srbija. Znanstveni interes: makroekonomija, primijenjena ekonometrija. Tel.:+38134303508. E-mail:nlojanica@kg.ac.rs.

4 Asistentica, Ekonomski fakultet, Sveučilište u Kragujevcu, Djure Pucara 3, 34000 Kragujevac, Srbija.Znanstveni interes: matematička ekonomija.Tel.:+38134303 552.E-mail: ojankovic@ kg.ac.rs. 


\section{Appendices}



Saša Obradović, Nemanja Lojanica, Olivera Janković • The influence of economic growth...

Table A1: OECD countries and its selected regions

\begin{tabular}{|c|c|c|c|}
\hline Country & $\begin{array}{c}\text { The biggest regional GDP } \\
\text { per head/The lowest regional } \\
\text { GDP per head }\end{array}$ & Country & $\begin{array}{c}\text { The biggest regional GDP per } \\
\text { head/The lowest regional GDP } \\
\text { per head }\end{array}$ \\
\hline \multirow{2}{*}{ Australia } & Western Australia & \multirow{2}{*}{ Italy } & Province of Bolzano-Bozen \\
\hline & Tasmania & & Campania \\
\hline \multirow{2}{*}{ Austria } & Vienna & \multirow{2}{*}{ Korea } & Chungcheong Region \\
\hline & Burgenland & & Gangwon Region \\
\hline \multirow{2}{*}{ Canada } & Northwest Territories & \multirow{2}{*}{ Netherlands } & West Netherlands \\
\hline & Prince Edward Island & & East Netherlands \\
\hline \multirow{2}{*}{ Chile } & Antofagasta & \multirow{2}{*}{ Norway } & Oslo and Akershus \\
\hline & Araucania & & Hedmark and Oppland \\
\hline \multirow{2}{*}{ Czech Republic } & Prague & \multirow{2}{*}{ Poland } & Mazovia \\
\hline & Northwest & & Podkarpacia \\
\hline \multirow{2}{*}{ Denmark } & Capital & \multirow{2}{*}{ Portugal } & Madeira \\
\hline & Zealand & & North \\
\hline \multirow[b]{2}{*}{ Finland } & Helsinki-Uusimaa & \multirow[b]{2}{*}{ Slovenia } & Western Slovenia \\
\hline & $\begin{array}{l}\text { Eastern and Northern } \\
\text { Finland }\end{array}$ & & Eastern Slovenia \\
\hline \multirow{2}{*}{ France } & Ile de France & \multirow{2}{*}{ Spain } & Basque Country \\
\hline & Limousin & & Extramadura \\
\hline \multirow{2}{*}{ Germany } & Hamburg & \multirow{2}{*}{ Sweden } & Stockholm \\
\hline & Thuringia & & North Middle Sweden \\
\hline \multirow{2}{*}{ Greece } & Athens & \multirow{2}{*}{ United Kingdom } & Greater London \\
\hline & Northern Greece & & Wales \\
\hline \multirow{2}{*}{ Hungary } & Central Hungary & \multirow{2}{*}{ United States } & District of Columbia \\
\hline & Northern Hungary & & Mississipi \\
\hline
\end{tabular}

Source: OECD Regional Demographic Statistics

Figure A1: Variables movement

\section{Australia}
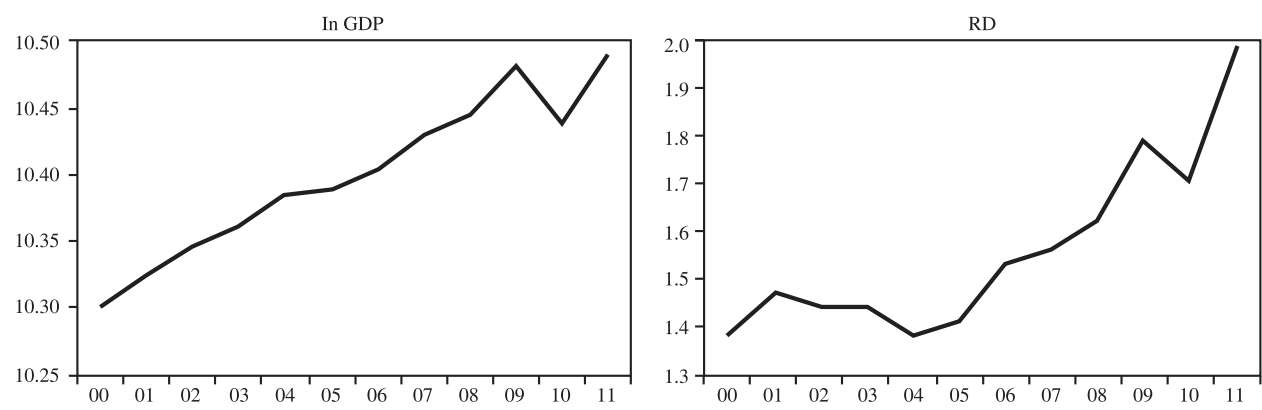


\section{Austria}
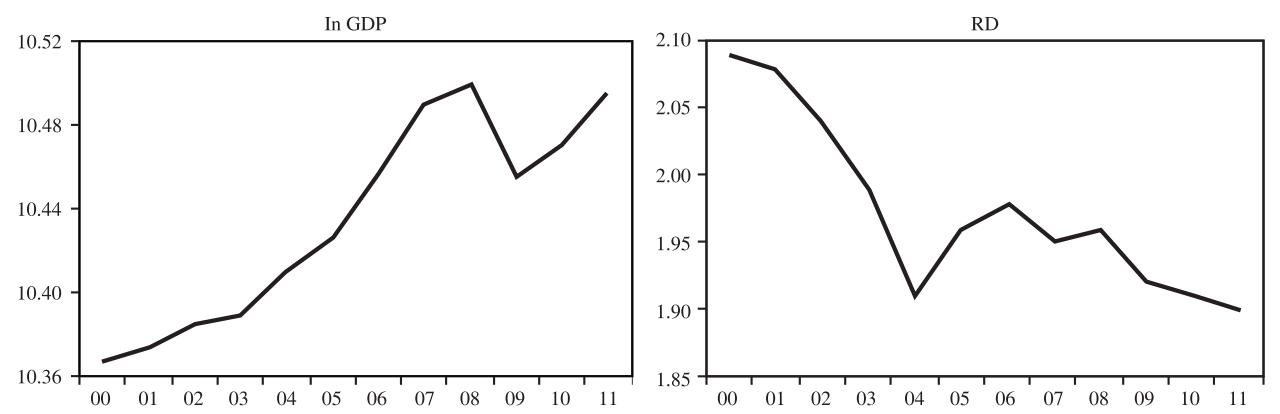

\section{Canada}
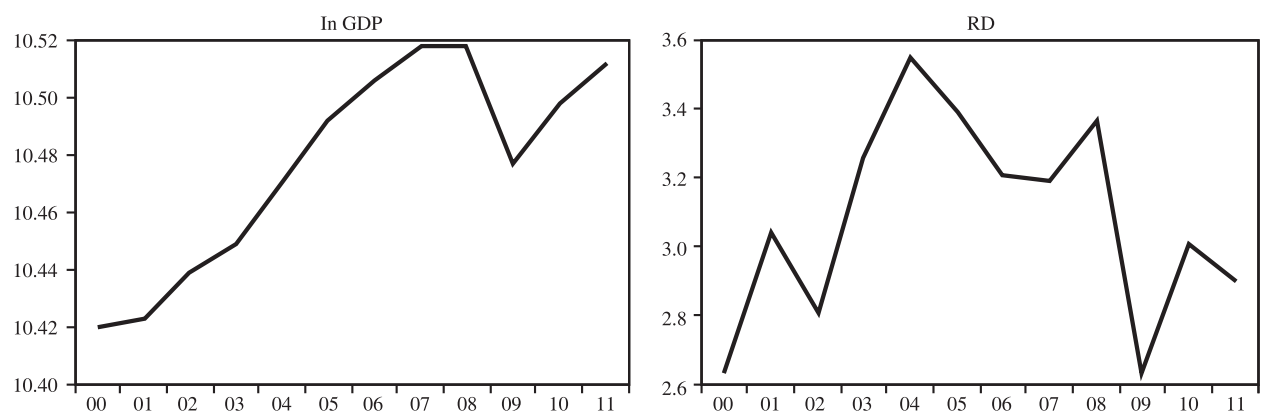

\section{Chile}
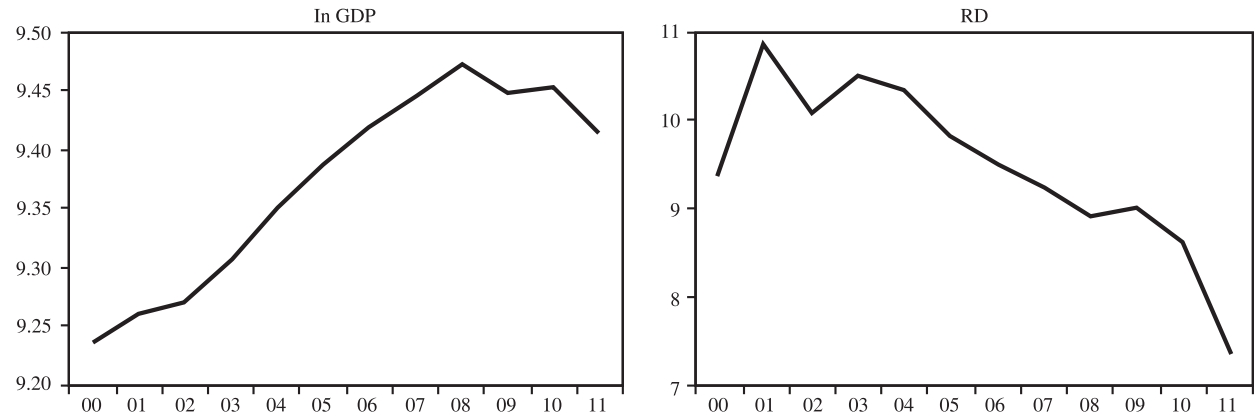
Saša Obradović, Nemanja Lojanica, Olivera Janković • The influence of economic growth...

\section{Czech Republic}
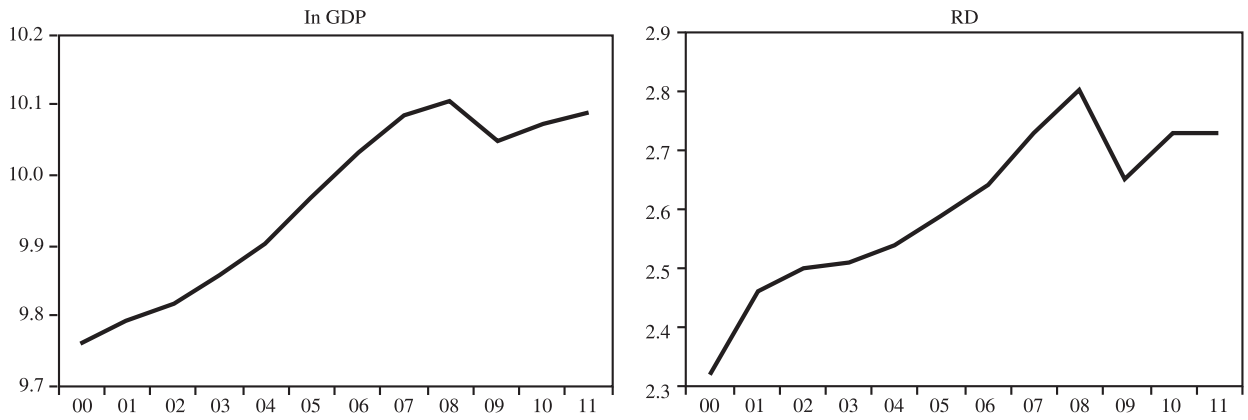

Denmark
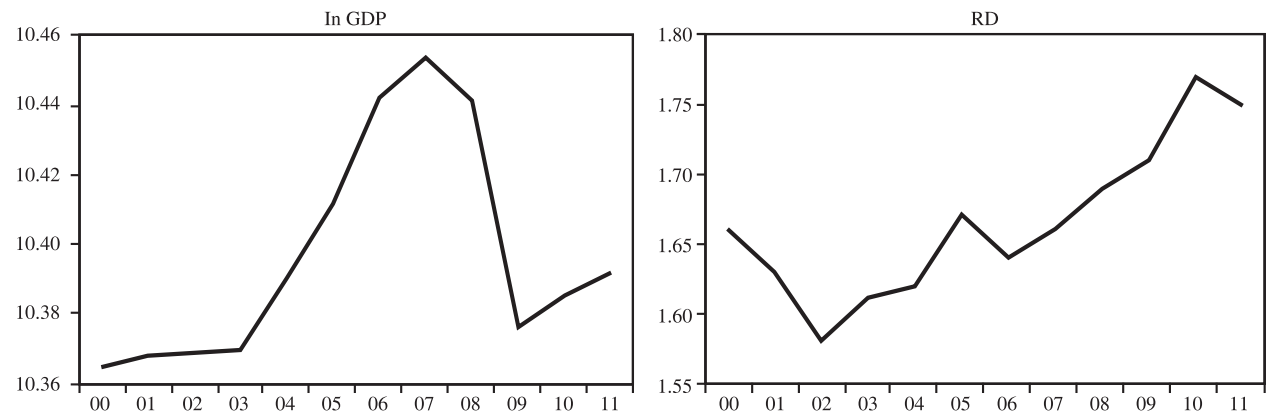

Finland
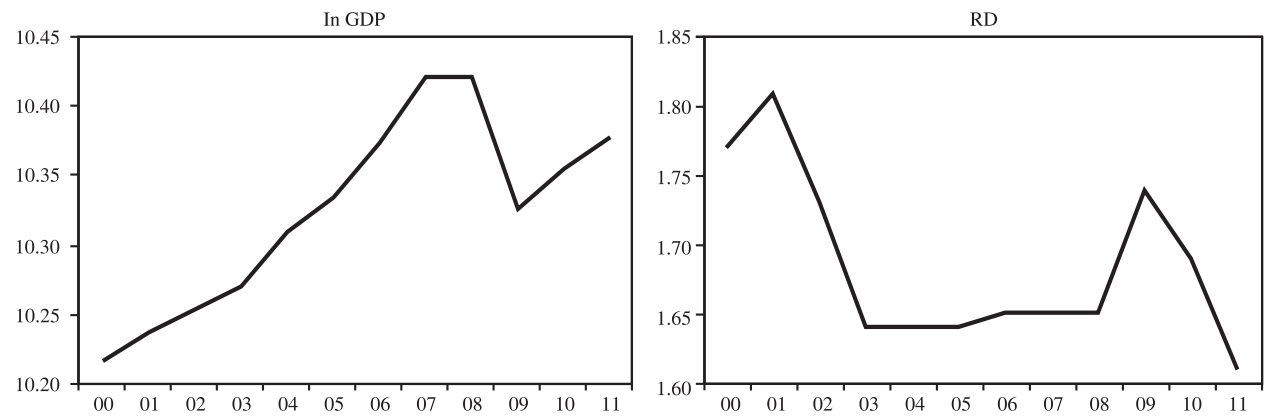


\section{France}
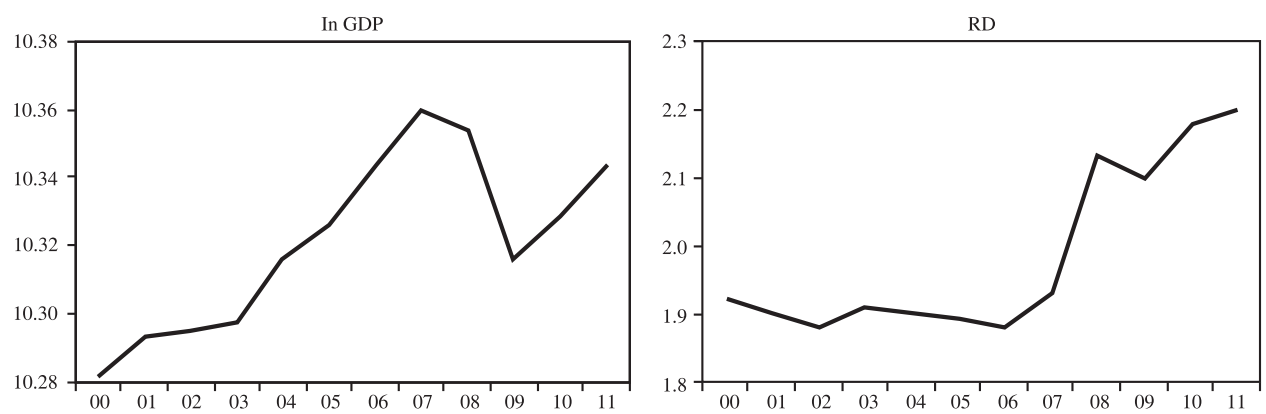

\section{Germany}
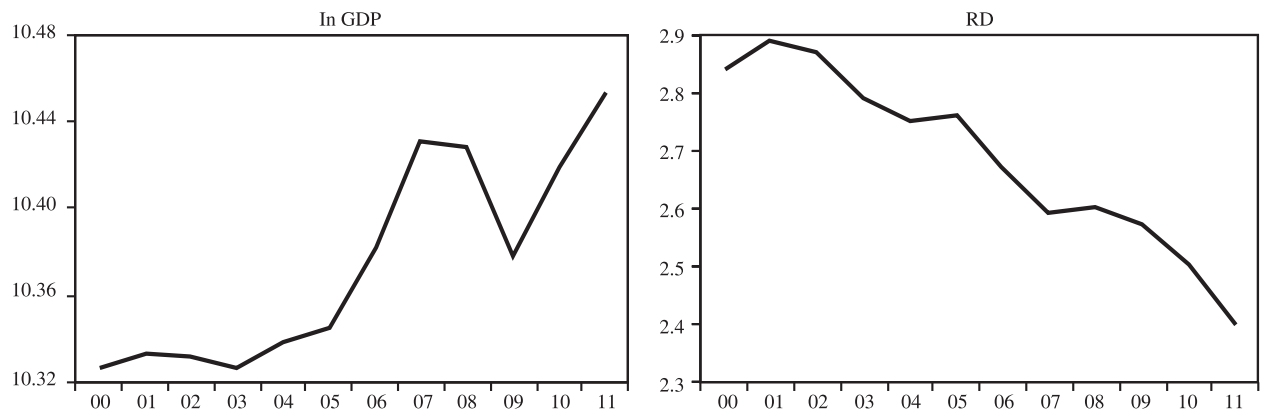

\section{Greece}
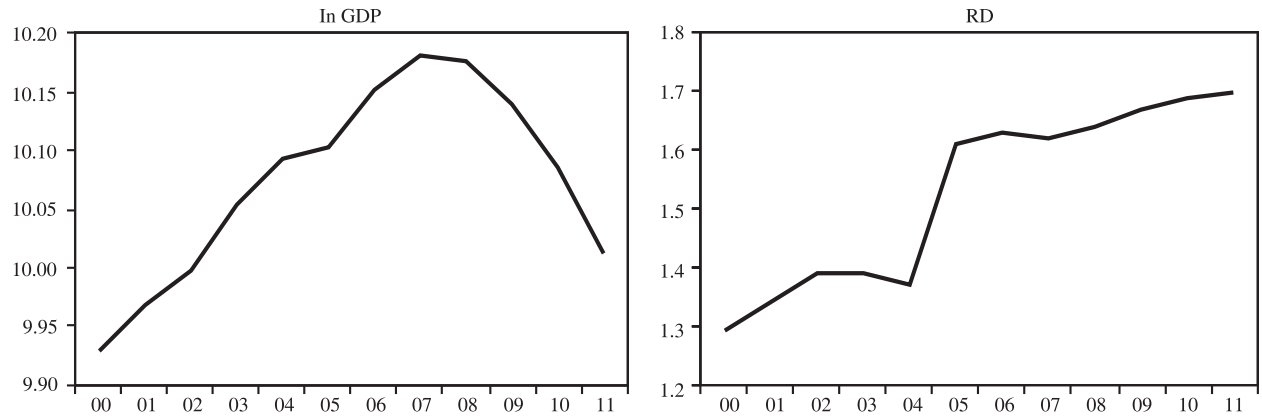
Saša Obradović, Nemanja Lojanica, Olivera Janković • The influence of economic growth...

\section{Hungary}
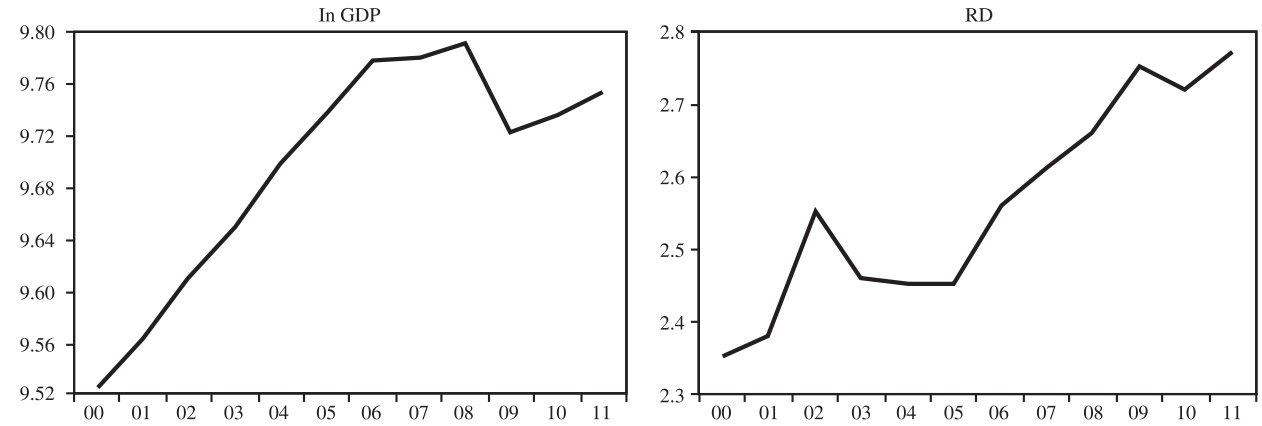

Italy
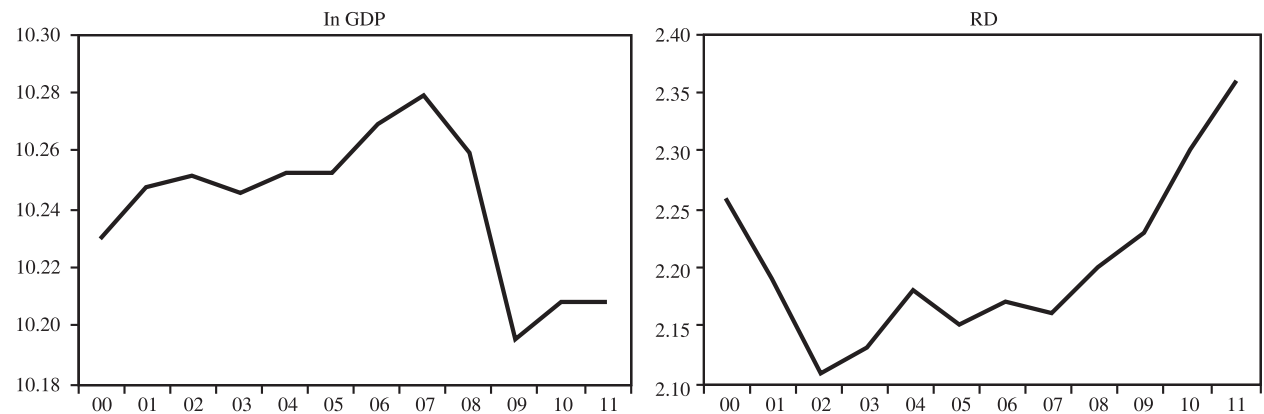

\section{Korea}
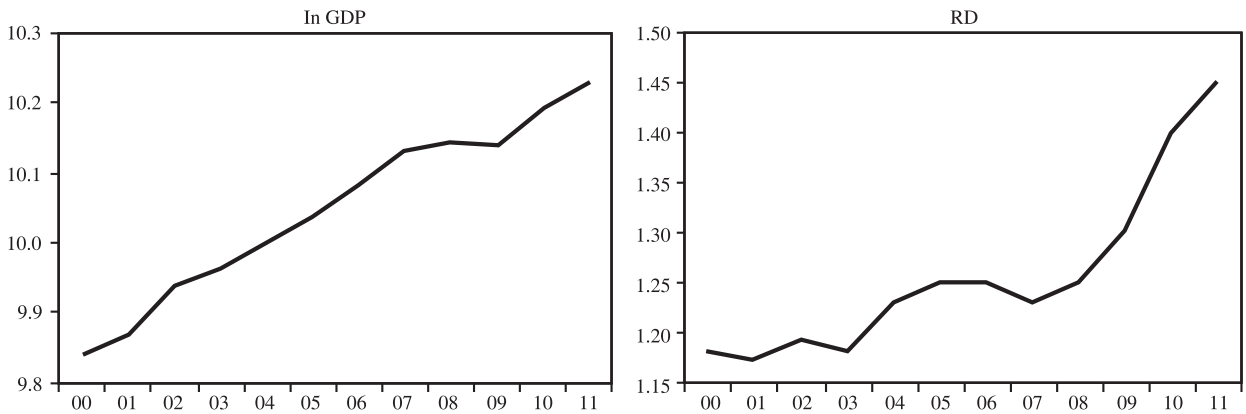


\section{Netherlands}
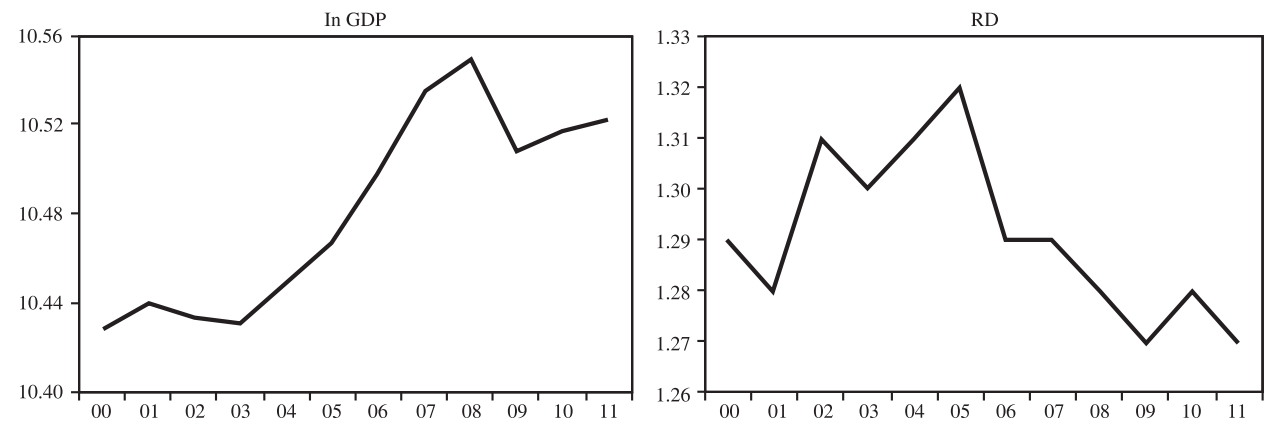

\section{Norway}
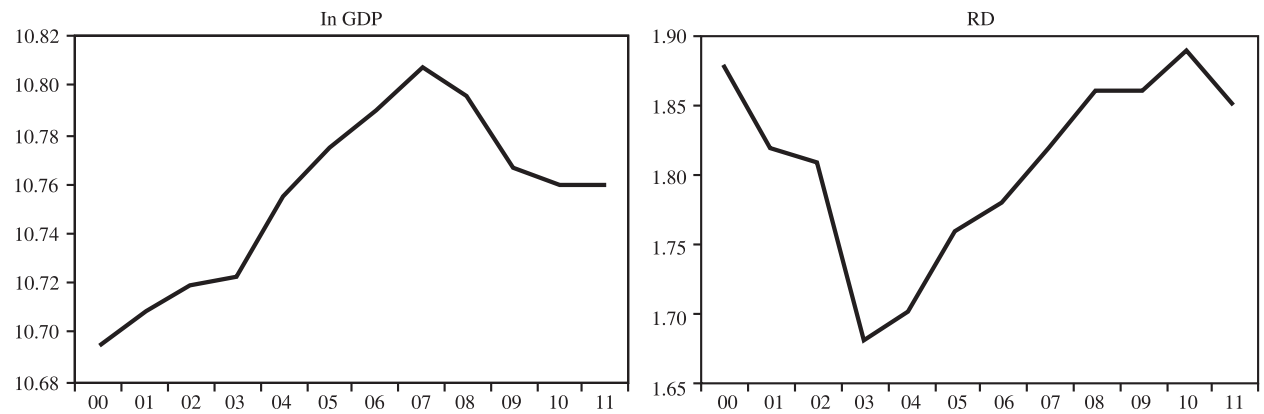

\section{Poland}
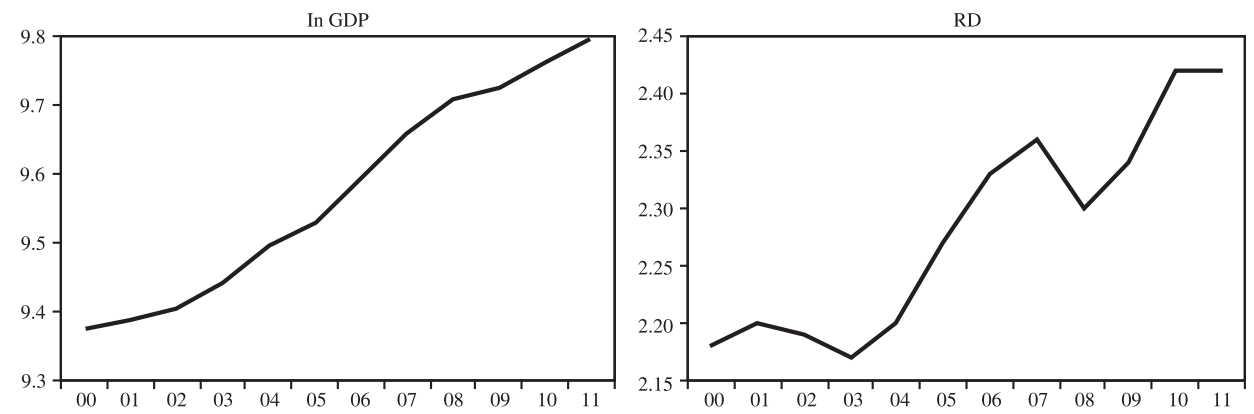
Saša Obradović, Nemanja Lojanica, Olivera Janković • The influence of economic growth...

\section{Portugal}
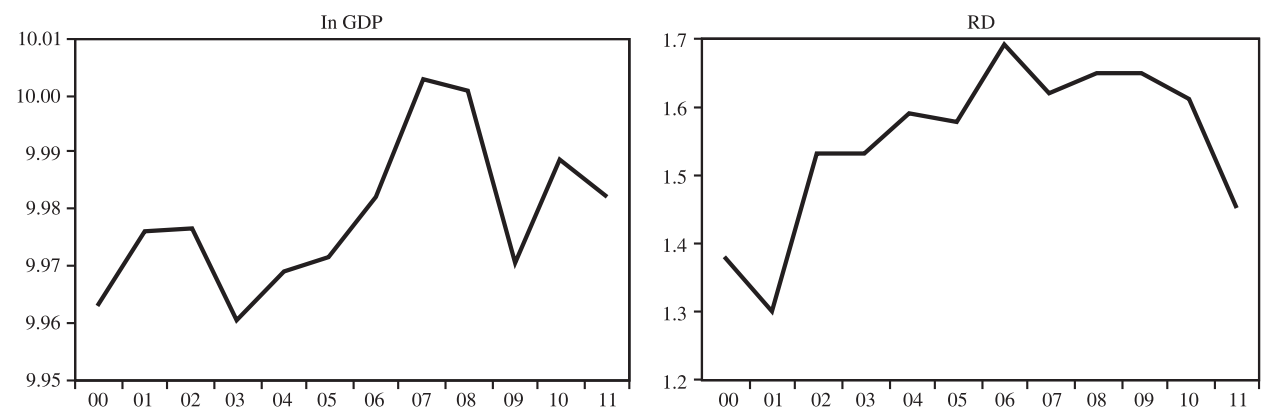

Slovenia
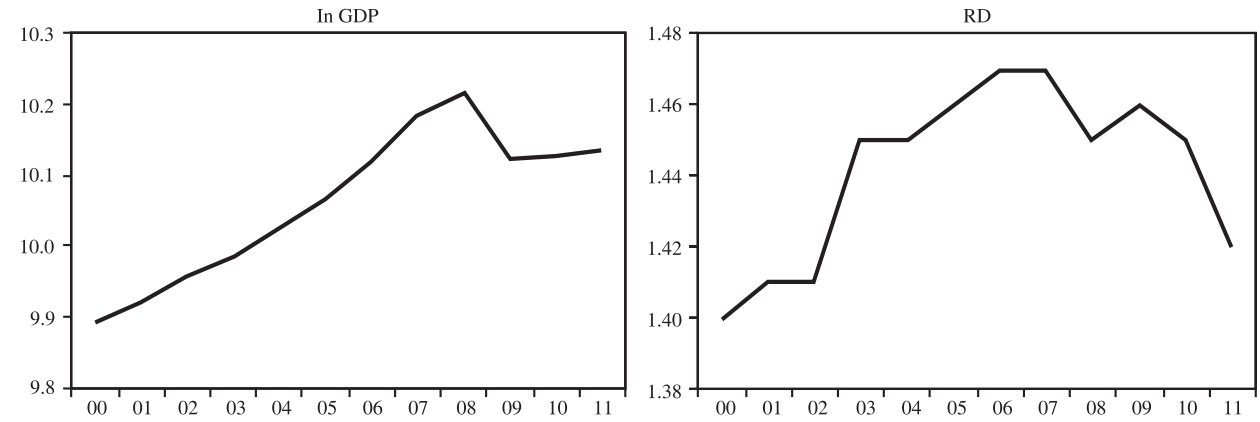

\section{Spain}
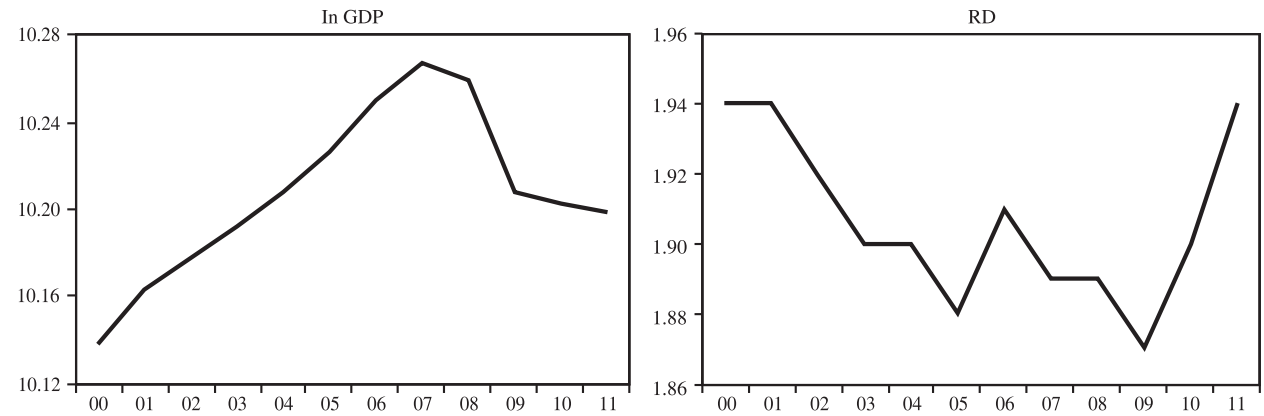


\section{Sweden}
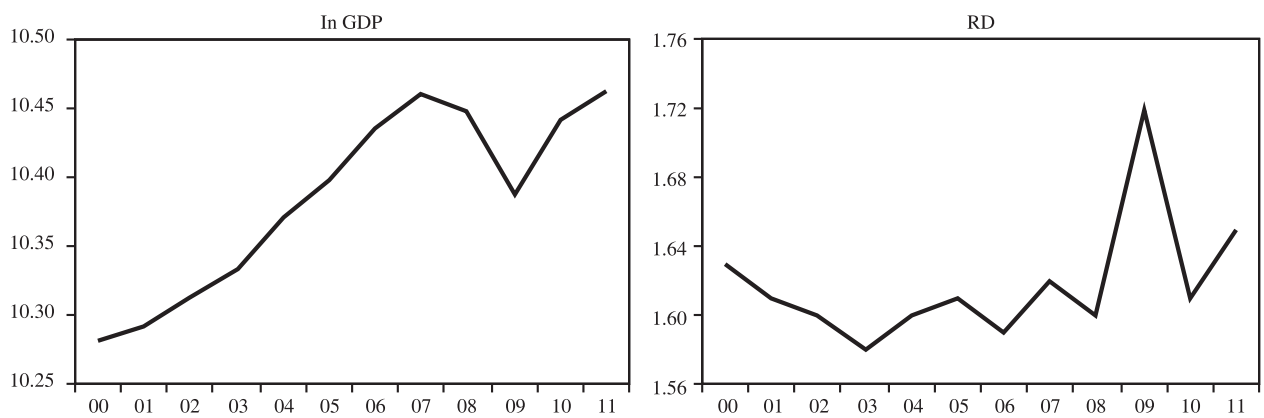

\section{United Kingdom}
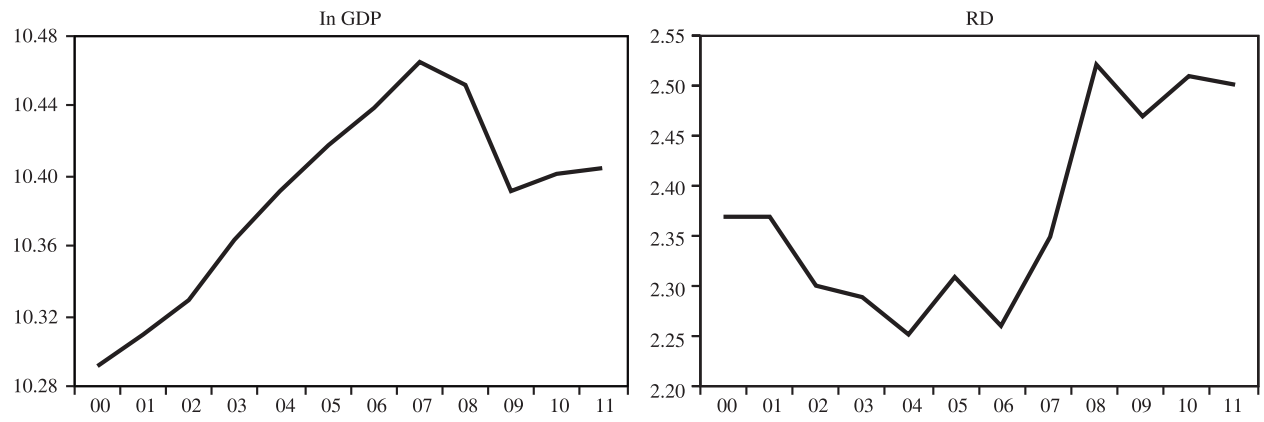

\section{United States}
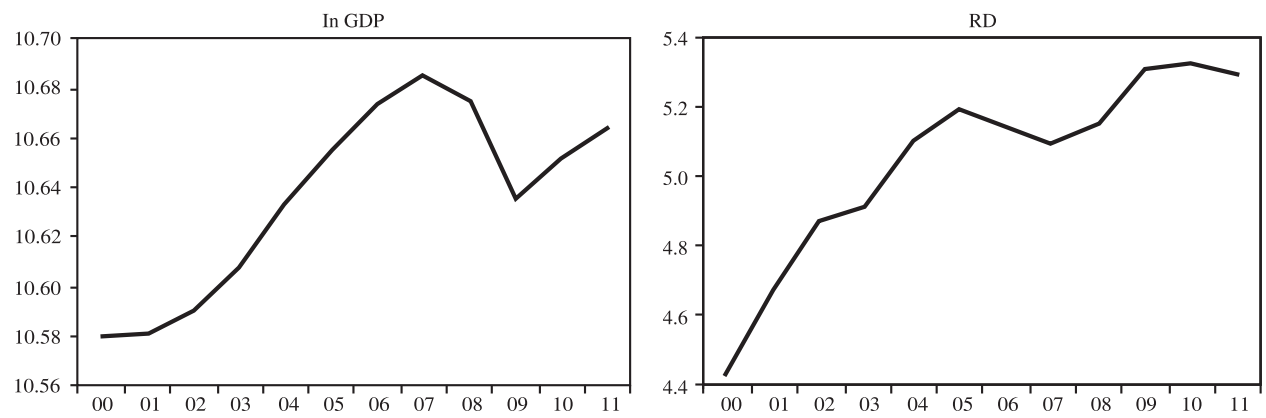

Source: Authors' graphs based on data from OECD Regional Demographic Statistics 